\title{
Frontières
}

\section{Bibliographie indicative sur la « bonne mort »}

\section{Jocelyne Saint-Arnaud}

Volume 20, numéro 1, automne 2007

La « bonne mort»

URI : https://id.erudit.org/iderudit/017966ar

DOI : https://doi.org/10.7202/017966ar

Aller au sommaire du numéro

Éditeur(s)

Université du Québec à Montréal

ISSN

1180-3479 (imprimé)

1916-0976 (numérique)

Découvrir la revue

Citer ce document

Saint-Arnaud, J. (2007). Bibliographie indicative sur la « bonne mort ».

Frontières, 20(1), 119-120. https://doi.org/10.7202/017966ar d'utilisation que vous pouvez consulter en ligne.

https://apropos.erudit.org/fr/usagers/politique-dutilisation/ 


\section{BIBLIOGRAPHIE INDICATIVE SUR LA «BONNE MORT »}

Jocelyne Saint-Arnaud

ABIVEN, M. (1995). Une éthique pour la mort. Paris, Desclée de Brouwer.

AGENCE DE SANTÉ PUBLIQUE DU CANADA (ASPC) (2002). Stratégie canadienne de lutte contre le cancer, rapport final du groupe de travail sur les soins palliatifs, janvier.

ARIÈS, P. (1977). Essai sur I'histoire de la mort en Occident, du Moyen Âge à nos jours, Paris, Éditions du Seuil.

ASSOCIATION CANADIENNE DE SOINS PALLIATIFS (ACSP) (2006). Normes de référence pan-canadiennes en matière de soins palliatifs à domicile: soins infirmiers palliatifs, décembre.

ASSOCIATION CANADIENNE DE SOINS PALLIATIFS (ACSP) (2002). Modèle de guide de soins palliatifs fondés sur les principes et les normes de pratique nationaux, mars.

ASSOCIATION QUÉBÉCOISE DE SOINS PALLIATIFS (AQSP) (2001). « Normes de pratique », Bulletin de I'AQSP, vol. 9, n० 1.

AURENCHE, S. (dir.) (2003). La mort devant soi. Euthanasie, des clés pour un débat, Paris, Éditions Autrement.

AYOUB, J. (2004). Guérir parfois, soulager souvent, réconforter toujours, Québec, Anne Sigier.

BACON, F. (1952 [1605]). The Advancement of Learning, cité dans Encyclopedia Britannica Inc., p. 52-53.

BERT, C. (2001). Éthique et santé. Les politiques sociales, avec la collab. de C. RENARD, nos 1 et 2 , Halle (Belgique).

BOLIN, J., C. PHILLIPS et C. HAWES (2006). « Urban and rural differences in end-of-life pain and treatment status on admission to a nursing facility ", The American Journal of Hospice \& Palliative Care, vol. 23, n० 1, p. 51-57.

BRANDT, R. (1992). Morality, Utilitarianism, and Rights, Cambridge, Cambridge University Press.

BRAZIL, K., D. HOWELL, M. BEDARD, P. KRUEGER et C. HEIDEBRECHT (2005). «Preference for place of care and place of death among informal caregivers of the terminally ill ", Palliative Medicine, vol. $19, n^{\circ} 6$, p. 492-499.

BROWN, M. (2000). «A good death. Principles of palliative care are yet to be applied in acute hospitals », British Medical Journal, vol. 320, n 7243, p. 1206.

CARTWRIGHT, J., S. HICKMAN, N. PERRIN et V. TILDEN (2006). «Symptom experiences of residents dying in assisted living ", Journal of the American Medical Directors Association, vol. 7, $\mathrm{n}^{\circ} 4$, p. 219-223.

CASSELL, E.J. (1982). "The nature of suffering and the goals of medicine ", The New England Journal of Medicine, vol. 306, n 11, p. 639-645.

CHERNY, N. (1996). «The problem of inadequately relieved suffering ", The Journal of Social Issues, vol. $52, n^{\circ} 2$, p. $13-30$.
CLARKE, D.M. (1999). "Autonomy, rationality and the wish to die", Journal of Medical Ethics, vol. $25, n^{\circ} 6$, p. 457-462.

CURTIS, M. (2003). «In search of a good death: Good death is social construction », British Medical Journal, vol. 327, n 7408, p. 223-224.

DANEAULT, S. (2006). Souffrance et médecine, Québec, Presses de l'Université du Québec.

DANEAULT, S., D. DION et E. HUDON (2002). « Les soins palliatifs, victimes de leur succès? Résultats d'une étude quantitative et qualitative ", Journal Européen de Soins Palliatifs, résumés du $\|^{e}$ Congrès du Réseau de Recherche de l'Association Européenne de Soins Palliatifs, p. 21.

DANEAULT, S., V. LUSSIER et S. MONGEAU (2006) "Primum non nocere: Could the health care system contribute to suffering? In-depth study from the perspective of terminally ill cancer patients ", Canadian Family Physician, vol. 52, $n^{\circ} 12$, p. 1574-5.

- (2004). «The nature of suffering and its relief in the terminally ill: A qualitative study ", Journal of Palliative Care, vol. 20, n 1, p. 7-11.

DECHÊNE, G., D. DION et J. GRATTON (2004). «Où meurent les Québécois? I. Recherche sur la population québécoise 1994 à 1998 ", Le médecin du Québec, vol. 39, n² ${ }^{\circ}$, p. 112-121.

DE HENNEZEL, M. (1995). La mort intime. Ceux qui vont mourir nous apprennent à vivre, Paris, Robert Laffond.

DENAULT, A.-M., (2003). Les conflits de valeurs et les dilemmes éthiques chez les infirmières gestionnaires de cas en contexte de rareté des ressources pour la clientèle des soins palliatifs, travail dirigé pour l'obtention d'une maîtrise en bioéthique.

DOUCET, H. (2003). « Le débat sur l'euthanasie et l'expérience du mourir », Frontières, vol. 16, n 1 , automne, p. 20-28.

DOUCET, H. (1988). Mourir. Approches bioéthiques, Paris, Desclée / Novalis.

ELLERSHAW, J. et C. WARD (2003). "Care of the dying patient: The last hours or days of life ", British Medical Journal, vol. 326, n 7379, p. 30-34.

FERRELL, B.R. (2005). " Late referrals to palliative care ", Journal of Clinical Oncology, vol. 23, n 12, p. 2588-2589.

FERRELL, B.R., D. NOVI, M.D. SULLIVAN, J. BANJA, M.Y. DUBOIS, M.C. GITLIN, D. HAMATY, A. LEBOVITS, A.G. LIPMAN, P.M. LIPPE et J. LILVVICH (2001). "Ethical dilemmas in pain management», The Journal of Pain, vol. 2, n³, p. 171-180

FLETCHER, J. (1967). Moral Responsibility: Situation Ethics at Work, Philadelphie, The Wesminster Press.

FRONTIÈRES (2005). SURTOUT NE PAS SOUFFRIR, vol. $17, \mathrm{n}^{\circ} 2$.

GLASER, B. et A. STRAUSS (1965). Awareness of Dying, Chicago, Aldine.

GOOD, M.D., N. GADMER et P. RUOPP (2004). « Narrative nuances on good and bad deaths: Internists' tales from high-technology work places», Social Science \& Medicine, vol. 58, nº 5, p. 939-953.
GRANDINETTI, D. (1999). «Ethical hope - A lifeline for sick patients ", Medical Economics, vol. 76, $\mathrm{n}^{\circ} 15$, p. 121-122.

GROGONO, J. (2000). "A good death. Sharing control in death: The role of an "amicus mortis" ", British Medical Journal, vol. 320, n 7243, p. 1205.

HADJISTAVROPOULOS, T. et K.D. CRAIG (dir.) (2004). "Ethical issues for psychologists», dans Pain, Psychological Perspectives, Maswah (New Jersey), Lawrence Erlbaum Associates Publishers, p. 327-344.

HAVE, H. ten (2005). «End-of-life decision making in the Netherlands", dans R.H. BLANK et J. C. MERRICK (dir.), End-of-Life Decision Making: A Cross-National Study, Cambridge, The MIT Press, p. 147-168.

HAWTON, K. (2007). «Restricting access to methods of suicide: Rationale and evaluation of this approach to suicide prevention ", CRISIS (The Journal of Crisis Intervention and Suicide Prevention), vol. 28, suppl. 1, p. 4-9.

HIGGINSON, I. et G. SEN-GUPTA (2000). «Place of care in advanced cancer: A qualitative systematic literature review of patient preferences », Journal of Palliative Medicine, vol. 3, n³, p. 287-300.

HINTERMEYER, P. (2003). Euthanasie, la dignité en question, Paris, Buchet / Chastel.

HORGAN, J. (1991). "Death with dignity: The Dutch explore the limits of a patient's right to die », Scientific American, mai, p. 17-20.

HUDON, F. (2005). " L'infirmière et le soulagement de la douleur ", Frontières, vol. 17, n² 2, p. 86-88.

HUMBERT, V. (2003). "Je vous demande le droit de mourir », propos recueillis et texte élaboré par F. VEILLE, Neuilly-sur-Seine, Éditions Michel Lafon.

HUME, D. (1783). Essays on Suicide and the Immortality of the Soul.

HUMPHREY, D. (1999). Final Exit, Eugene (OR), The Hemlock Society.

HUMPHREY, D. (1986). «The case for rational suicide ", Euthanasia Review, vol. 1, n³, p. 172-176.

INSTITUT NATIONAL DE SANTÉ PUBLIQUE DU QUÉBEC (INSPQ) (2006). Soins palliatifs de fin de vie du Québec: Définition et mesure d'indicateurs, partie 1, avril.

INTERNATIONAL ASSOCIATION FOR THE STUDY OF PAIN (IASP) (1995). Opioïds for chronic noncancer pain. Pain Clinical Updates III (3).

JONES, J. et D. WILLIS (2003). «In search of a good death: What is a good death? ", British Medical Journal, vol. 327, n 7408, p. 224.

KEHL, K. (2006). "Moving toward peace: An analysis of the concept of a good death », The American Journal of Hospice \& Palliative Care, vol. 23, n 4, p. 277-286.

KÜBLER-ROSS, E. (1969). On Death and Dying, New York, Macmillan.

LAMBERT, P. et M. LECOMPTE (2000). Le citoyen: une personne du début - à la fin de sa vie: rapport principal sur l'état de situation des soins palliatifs au Québec, Québec, Ministère de la Santé et des Services sociaux, Direction des communications. 
LAPUM, J. (2003). «In search of a good death: A good death and medicalisation need not be polarised", British Medical Journal, vol. 327, $\mathrm{n}^{\circ} 7408$, p. 224-225.

LE BRETON, D. (2000). «Aspects sociaux et culturels de la douleur », dans G. METZGER, A. MULLER, M. SCHWETTA et C. WALTER (dir.), Soins infirmiers et douleur, Paris, Masson, p. 120-127.

LIBOVITZ, A. (2001). "Ethics and pain. Why and for whom?", Pain Medicine, vol. 2, n², p. 92-96.

LYNN, J., J.M. TENO et R.S. PHILLIPS (1997). «Perceptions by family members of the dying experience of older and seriously ill patients", Annals of Internal Medicine, vol. 126, $\mathrm{n}^{\circ} 2$, p. 97-106.

MARCOUX, I., B.L. MISHARA et C. DURAND (2007). "Confusion between euthanasia and other end of life decisions: Influences on public opinion poll results", Canadian Journal of Public Health, vol. 98, n³ 3, p. 235-239.

MAY, W.E. (1978). "Double Effect», dans W.T. REICH (dir.), Encyclopedia of Bioethics, New York, The Free Press, tome I, p. 316.

MAYO, D.J. (1983). «Contemporary philosophical literature on suicide: A review», Suicide and LifeThreatening Behavior, vol. 13, nº 4, p. 313-345.

MCNAMARA, B., C. WADDELL et M. COLVIN (1994). "The institutionalization of the good death ", Social Science \& Medicine, vol. 39, n 11 , p. 1501-1508.

MEIER, D., C. EMMONS, A. LITKE, S. WALLENSTEIN et R. MORRISON (2003). "Characteristics of patients requesting and receiving physicianassisted death ", Archives of Internal Medicine, vol. 163, n 13, p. 1537-1542.

MINISTÈRE DE LA SANTÉ ET DES SERVICES SOCIAUX (MSSS) (2006). Les accidents évitables dans la prestation des soins de santé - Rapport du groupe de travail sur I'utilisation des opiacés en milieu hospitalier, juin.

MINISTÈRE DE LA SANTÉ ET DES SERVICES SOCIAUX (MSSS) (2004). Politique en soins palliatifs de fin de vie, Québec, Gouvernement du Québec.

MISHARA, B.L. (1999). « Synthesis of research and evidence on factors affecting the desire of terminally ill or seriously chronically ill persons to hasten death ", Omega, International Journal on Death and Dying, vol. 39, $\mathrm{n}^{\circ}$ 1, p. 1-70.

MISHARA, B.L. (1998). "The right to die and the right to live: Perspectives on euthanasia and assisted suicide", dans A. LEENARS, M. KRAL, R. DYCK et S. WENCKSTERN (dir.), Suicide in Canada, Toronto, University of Toronto Press, p. 441-458.

MORE, T. (1952 [1615]). L'Utopie, traduit par V. STOUVENEL, Paris, Éditions sociales.

MOULIN, D.E., A.J. CLARCK, M. SPEECHLEY, D.E. MORLEY et P. K. MOULIN (2002). «Chronic pain in Canada - Prevalence, treatment, impact and the role of opioid analgesia ", Pain Research and Management, vol. 7, n 4, p. 179-184.

MUNN, J. et S. ZIMMERMAN (2006). "A good death for residents of long-term care: Family members speak ", Journal of Social Work in Endof-Life \& Palliative Care, vol. 2, n 3, p. 45-59.
NÉRON, A. (2005). «Derrière le miroir de la douleur, les interractions médicamenteuses, quiétude ou inquiétude? ", Frontières, vol. 17, n² 2, p. 42-52.

OREGON DEPARTMENT OF HUMAN SERVICES (2005). Seventh Annual Report on Oregon's Death With Dignity Act, State of Oregon.

ORGANISATION MONDIALE DE LA SANTÉ (OMS) (2004). Politique en soins palliatifs de fin de vie.

ORR, R.D. (2001). « Pain management rather than assisted suicide: The ethical high ground ", Pain Medicine, vol. 2, n² 2, p. 131-137.

POHIER, J. (1997). La mort opportune, Les droits des vivants sur la fin de leur vie, Paris, Le Seuil, Points Essais.

PROULX, K. et C. JACELON (2004). "Dying with dignity: The good patient versus the good death ", The American Journal of Hospice \& Palliative Care, vol. 21, nº 2, p. 116-120.

RACHELS, J. (1986). The End of Life: Euthanasia and Morality, Oxford, Oxford University Press.

RAMSAY, P. (1978). Ethics at the Edge of Life, New Haven, Yale University Press.

SAINT-ARNAUD, J. (2005). "De I'approche biomédicale à l'art du soin ", Frontières, vol. $17, n^{\circ} 2$, p. 34-41.

SAINT-ARNAUD, J. (1999). Enjeux éthiques et technologies biomédicales, Montréal, PUM.

SAUNDERS, C. (1978). The Management of Terminal Disease, Londres, Edward Arnold.

STAGNARO, S. (2003). «What is a good death? Good death will happen if life was good $"$, British Medical Journal, vol. 327, nº 7422, p. 1047.

THE, A., T. HAK, G. KOETER, et G.V.D. WAL (2000). «Collusion in doctor-patient communication about imminent death: An ethnographic study ", British Medical Journal, vol. 321, nº 7273, p. $1376-81$

TWYCROSS, R.G. (1982). «Euthanasia: A Physician Viewpoint ", Journal of Medical Ethics, $n^{\circ} 8$, p. 86-95.

VAN DER MAAS, P.J., G. VAN DER WAL, I. HAVERKATE, C.L.M. DE GRAAF, J.G.C. KESTER, B.D. ONWUTEAKA-PHILIPSEN et al. (1996). "Euthanasia, physician-assisted suicide, and other medical practices involving the end of life in the Netherlands, 1990-1995", New England Journal of Medicine, vol. 335, n 1, p. 699-705.

VIG, E., N. DAVENPORT et R. PEARLMAN (2002). "Good deaths, bad deaths, and preferences for the end of life: A qualitative study of geriatric outpatients", Journal of the American Geriatrics Society, vol. 50, n 9, p. 1541-1558.

VIG, E. et P. PEARLMAN (2004). "Good and bad dying from the perspective of terminally ill men ", Archives of Internal Medicine, vol. 164, n० 9, p. $977-981$.

WALTERS, G. (2004). «Is there such a thing as a good death ?", Palliative Medicine, vol. 18, $n^{\circ} 5$, p. 404-408.

WAY, J., A.L. BACK et J.R. CURTIS (2001). «Withdrawing life support and resolution of conflict with families", British Medical Journal, vol. 325, p. 1342-1345.

\section{NOUVELLES PARUTIONS-} ÉTUDES SUR LA MORT

Ngoc-Thanh Phan Nguyen

AUPETIT, Michel (2007). La mort, et après ?: un prêtre médecin témoigne et répond aux interrogations, $2^{\mathrm{e}}$ éd. rév., Paris, Salvator.

BONDOLFI, Alberto (2007). La mort assistée: en arguments, Chêne-Bourg (Suisse), Georg, coll. «Controverses en éthique ", $n^{\circ} 2$.

BOUTINET, Jean-Pierre (2007). Penser l'accompagnement adulte: ruptures, transitions, rebonds, Paris, Presses universitaires de France.

CUEVAS, Bryan J. (2007). The Buddhist Dead: Practices, Discourses, Representations, Honolulu (Hawaii), University of Hawaii Press.

DEREGNAUCOURT, Jean-Pierre (2007). La mort au Moyen Âge: les hommes et la mort à la fin du Moyen Âge, Paris, J.-P. Gisserot, coll. "Gisserot Histoire».

FELDMAN, David B. (2008). End-Of-Life Handbook: A Compassionate Guide to Connecting with and Caring for a Dying Loved One, Oakland (CA), New Harbinger.

GAGNET, Élise et Michaëlle GAGNET (2007). La mort apaisée: chroniques d'une infirmière en soins palliatifs, Paris, La Martinière.

GANNAL, Jean-Nicolas (2007). History of Embalming and of Preparations in Anatomy, Pathology and Natural History, Chicago, Kessinger Publishing.

GORMAN, Martha et Jennifer Fecio McDOUGALL (2007). Euthanasia: A Reference Handbook, $2^{\mathrm{e}}$ éd., Santa Barbara (CA), ABC-Clio.

IRETON, Sean (2007). An Ontological Study of Death: From Hegel to Heidegger, Pittsburgh (PA), Duquesne University Press.

JONES, David Albert (2007). Approaching the End: A Theological Exploration of Death and Dying, New York, Oxford University Press.

JOYEUX, Henri (2007). Le suicide, Paris, F.-X. de Guibert.

KALINA, Kathy (2007). Midwife for Souls, Spiritual Care for the Dying: A Pastoral Guide for Hospice Care Workers and All Who Live with the Terminally III, Boston (MA), Pauline Books \& Media.

OLIVIER, Abraham (2007). Being in Pain, New York, Peter Lang.

OPPENHEIM, Daniel (2007). Parents: comment parler de la mort avec votre enfant?, Bruxelles, De Boeck, coll. «Parentalités ».

RAIMBAULT, Ginette (2007). Parlons du deuil, Paris, Payot, coll. "Petite bibliothèque Payot», $\mathrm{n}^{\circ} 643$.

SERRIE, Alain (2007). Vaincre la douleur: la souffrance $n$ 'est pas toujours une fatalité, Neuillysur-Seine (Hauts-de-Seine), Michel Lafon. 